\title{
Effect of regulated deficit irrigation (RDI) on the vegetative growth of pear variety Triunfo de Viena (Pyrus communis L.)
}

\section{Efecto del riego deficitario controlado (RDC) en el crecimiento vegetativo del peral variedad Triunfo de Viena (Pyrus communis L.)}

\author{
Javier Enrique Vélez-Sánchez ${ }^{1}$; María Jaqueline Molina-Ochoa ${ }^{2}$ Pedro Rodríguez-Hernández ${ }^{3}$
}

\begin{abstract}
1Agricultural Engineer. Universidad Nacional de Colombia, Department of Civil and Agricultural Engineering. Bogotá, Colombia; e-mail: jevelezs@unal.edu.co; (D) https://orcid.org/0000-0002-1361-8374

${ }^{2}$ Agricultural Engineer. Universidad Nacional de Colombia, Department of Civil and Agricultural Engineering. Bogotá, Colombia; e-mail: mjmolinao@unal.edu.co; (1D) https://orcid.org/0000-0001-7839-9988
\end{abstract}

${ }^{3}$ Agricultural Engineer. Corporación Colombiana de Investigación Agropecuaria -Agrosavia-, Department of plant Physiology. C.I. Obonuco. Colombia; e-mail: pedror@agrosavia.co; (D) https://orcid.org/0000-0001-7351-0595

How to cite: Vélez-Sánchez, J.E.; Molina-Ochoa, M.J.; Rodríguez-Hernández, P. 2021. Effect of regulated deficit irrigation (RDI) on the vegetative growth of pear variety Triunfo de Viena (Pyrus communis L.). Rev. U.D.C.A Act. \& Div. Cient. 24(2):e2007. http://doi. org/10.31910/rudca.v24.n2.2021.2007

Open access article published by Revista U.D.C.A Actualidad \& Divulgación Científica, under Creative Commons License CC BY-NC 4.0

Official publication of the Universidad de Ciencias Aplicadas y Ambientales U.D.C.A, University, Accredited as a High-Quality Institution by the Colombian Ministry of Education.

Received: February 20, $2020 \quad$ Accepted: June 6, 2021

Edited by: Ingeborg Zenner de Polanía

\section{ABSTRACT}

One of the consequences of a water deficit in the vegetative growth is the modification of the plant vigor, which determines the extent and the rate of growth and lengthening in shoots, which, in this phase, is more important than fruit growth, which is very slow in terms of dry mass accumulation. The objective of this research was to determine the effect on the vegetative growth of the pear variety Triunfo de Viena (Pyrus communis L) of regulated deficit irrigation (RDI), which was compared with a control irrigated at 100\% crop evapotranspiration (ETc). The irrigation treatments consisted of the application of watering regimes of 74 and $48 \%$ ETc in treatment T2 and 60 and 27\% ETc in treatment T3 in 2014 and 2015, respectively, during the period of rapid fruit growth with the same watering regime used in T1 (control) applied during the rest of the season. The irrigation reduction used in T2 and T3 represented water savings of $26 \%$ and $40 \%$ in 2014 and $52 \%$ and $73 \%$ in 2015 , respectively. In the deficit treatments, there were no significant differences with respect to the control for the length, or absolute and relative growth rates (AGR and RGR) of the shoots. The weight of the wood from the fructification pruning had a significant difference between T3 and the control.

Keywords: Water; Wood; Pear; Fruit; Irrigation.

\section{RESUMEN}

Una de las consecuencias del déficit hídrico en el crecimiento vegetativo es la modificación del vigor de la planta, que determina la extensión y el ritmo de crecimiento y de alargamiento de los brotes 
que, en esta fase, es más importante que el crecimiento del fruto, el cual, es bastante lento, en términos de acumulación de masa seca. El objetivo de esta investigación fue determinar el efecto sobre el crecimiento vegetativo del peral variedad Triunfo de Viena (Pyrus communis L.) del riego deficitario controlado (RDC), que se comparó con un Control, regado al 100\%, de la evapotranspiración del cultivo ETc. Los tratamientos de riego consistieron en la aplicación de láminas de agua, correspondiente al 74 y $48 \%$ de la ETc, en el tratamiento T2 y 60 y $27 \%$ de la ETc, en el tratamiento T3, en 2014 y 2015, respectivamente; durante el periodo de crecimiento rápido del fruto, mientras el resto de la temporada, todos se regaron igual que el T1 (control). La reducción de la lámina de riego en T2 y T3, durante este periodo, representó un ahorro de agua de 26 y 40\%, en 2014 y 52 y $73 \%$, en 2015, respectivamente. En los tratamientos deficitarios no hubo diferencias significativas respecto al control, en el diámetro, la longitud, la tasa absoluta y la relativa de crecimiento (TAC y TRC) de brotes. En la masa de madera correspondiente a la poda de fructificación, se presentó diferencia significativa, entre el T3 y el control.

Palabras clave: Agua; Madera; Pera; Fruta; Riego.

\section{INTRODUCTION}

An alternative that improves water use efficiency in fruit trees is RDI, which consists of making small water applications during periods of the crop cycle that have low sensitivity to water deficits and applying the necessary amount during the rest of the phenological cycle (Vélez Sánchez et al. 2012). Monitoring the evolution of the daily growth of buds allows for controlling the intensity of deficits to avoid losses in fruit production and quality (Moreno Hernández et al. 2017).

The vigor conditions of plants determine the extent, rate of growth, and elongation of shoots; a high-water deficit can affect trees or their parts (Bolat et al. 2014). The effect depends on the intensity, duration, and timing of the deficit. Imposing moderate levels of water stress during crop development improves fruit quality and saves water (Silveira et al. 2020).

The initiation and differentiation of vegetative and reproductive structures and cell lengthening once the cells are differentiated are very sensitive to water stress and, physiological processes, are not necessarily affected to the same degree (Marsal et al. 2002). Wu et al. (2013) and Molina Ochoa et al. (2015b), in the pear, found that the effect of water stress manifests itself clearly in vegetative growth, so one of the objectives of RDI is to avoid the excess vigor that affects fructification (Vélez Sánchez et al. 2007). Vegetative development is limited proportionally to reductions in the water supply (Moreno Hernández et al. 2017).

Growth curves show the behavior of a plant in a particular ecosystem over time, irreversible increases in dry matter or volume, and changes in size, mass, shape, or number of structures as a function of genotype and environment, resulting in a quantitative increase in the size and weight of the plant or a specific organ
(Álvarez et al. 2021). The growth rates commonly used for analyses are absolute growth rate (AGR), which indicates changes in size per unit of time, and relative growth rate (RGR), which indicates variation in size per unit of initial size (Ardila et al. 2011).

The objective of the research was to determine the effect on the vegetative growth of the pear variety Triunfo de Viena of regulated deficit irrigation RDI during the rapid fruit growth stage in 2014 and 2015, taking into account the water status of the soil and of the plants.

\section{MATERIALS AND METHODS}

This experiment was carried out during 2014 and 2015 in the municipality of Sesquilé, Cundinamarca, Colombia, on a plot of $0.32 \mathrm{ha}$, with 172 pear trees of the variety Triunfo de Viena, planted in 1998 at $4 \times 4 \mathrm{~m}$. The soil, typical of the area has a clay-loam texture (IGAC, 2010). The weather information was obtained from a WS-GP1 portable weather station (AT delta-T Devices, USA) located next to the plot. The climate is cold and dry, the average temperature was $13.0^{\circ} \mathrm{C}$ and $13.14^{\circ} \mathrm{C}$, relative humidity was 80.17 and $79.78 \%$, and accumulated precipitation was $509.6 \mathrm{~mm}$ and $820 \mathrm{~mm}$ for 2014 and 2015. The mean potential evapotranspiration (ETo), calculated with the Penman-Monteith equation (Allen $e t$ al. 1998; Cleves Legizamo et al. 2016), was 2.09 and $2.03 \mathrm{~mm} \mathrm{day}^{-1}$ in 2014 and 215, respectively.

The experiment design consisted of randomized complete blocks, taking into account the slope of the land and the distribution of the trees in the plot, with three treatments and four repetitions (12 plots); the experimental plot was formed by 4 or 5 contiguous rows of three, four and five trees each (with a total of 12, 15, 16 and 20 interior trees per plot).

The irrigation regime was determined by taking into account crop evapotranspiration (ETc). During the crop cycle, all treatments were irrigated at $100 \% \mathrm{ETc}$; in the rapid fruit growth phase, the following were applied: Control Treatment (T1), irrigated for two years at 100\% ETc; and Deficit Treatments (T2), irrigated at $74 \%$ and $48 \% \mathrm{ETc}$, and (T3), irrigated at $60 \%$ and $27 \% \mathrm{ETc}$, in 2014 and 2015, respectively. The volume of water applied to each treatment was controlled by varying the irrigation time, maintaining the same frequency, every two days. The water was measured with $13 \mathrm{~mm}$ volumetric counters (Zenner $\left.{ }^{\circledR}\right)$ installed in each plot. The drip irrigation system used six $8 \mathrm{Lh}^{-1}$ emitters per tree.

The water matrix potential in the soil $(\Psi \mathrm{s})$ was measured every three days with eight granular matrix sensors (Watermark Mod. 200ss Irrometer Co., USA) per treatment, installed at depths of 15 and $30 \mathrm{~cm}$ every $25 \mathrm{~cm}$ on the emitter and drip line.

The leaf water potential was measured with a pressure chamber (PMS Instrument Company, Model 600, PMS Instrument Company, Oregon, USA). The determinations were made on leaves before dawn (potential at dawn, $\Psi$ a) and at solar noon (potential stem, $\Psi \mathrm{t})$ on leaves in which transpiration was prevented by covering 
them two hours before the measurement with hermetically sealed plastic bags covered with aluminum foil. For both the $\Psi \mathrm{a}$ and $\Psi \mathrm{t}$, two and three adult leaves were used per tree from three and four representative trees per treatment in 2014 and 2015, respectively, which were located in the lower third on the north side of the tree. The determinations were made at the beginning of the water restrictions and every month thereafter for the $\Psi_{\mathrm{a}}$ and every 15 days for the $\Psi \mathrm{t}$.

On October 1 and 2 of 2013 and 2014 and September 20 of 2015, fruit pruning was carried out; after the harvest, the wood corresponding to two trees was weighed per repetition, for a total of eight per treatment, to determine whether the water regimes affected the vegetative development.

In November 2013 and 2014, 12 shoots, with an average length of $10 \mathrm{~cm}$, were selected and labeled by three in two trees per repetition, for a total of 96 per treatment, half on the north side and half on the south side, on which the length was measured in 2014 and 2015 , every eight days with a precision flexometer $(0.01 \mathrm{~mm})$ until harvest (May 9 of 2014 and April 10 of 2015). The growth curves were fitted to a three-parameter sigmoid logistic (Equation 1).

$\mathrm{y}=\frac{\mathrm{a}}{1+\mathrm{e}^{-\left(\frac{\mathrm{x}-\mathrm{c}}{\mathrm{b}}\right)}}$

equation 1.

The (AGR) of the bud length corresponded to the growth derivative $(\delta y / \delta \mathrm{t})$, which resulted in equation 2 , with the parameters of the models obtained from the growth curves sigmoid logistic equation.

$$
\frac{d y}{d y}=\frac{a e^{-\left(\frac{x-c}{b}\right)}}{b\left(1+e^{-\left(\frac{x-c}{b}\right)}\right)^{2}}
$$

equation 2 .

The absolute growth rate was calculated with equation 3

$$
(1 / y)(\delta y / \delta t)
$$

equation 3 .

With the SAS/STAT program (SAS Institute Inc, 2010), the statistical analysis was carried out using analysis of variance and Tukey test, $\mathrm{p}<0.05$, to compare the treatments and the control with the "glm" procedure.

\section{RESULTS AND DISCUSSION}

The volume of water applied. The irrigation treatments applied during the restriction from January 1 to February 28, 2014, 67.6, 49.8, and 40.9 $\mathrm{mm} \mathrm{ha}^{-1}$ and, from December 23, 2014, to February 22, 2015, 48.3, 23.3, and $13.1 \mathrm{~mm} \mathrm{ha}^{-1}$ to T1, T2, and T3, respectively. The amount of water supplied during the restriction was greater in 2014, coinciding with the weather conditions. The irrigation reduction in T2 and T3 during this period represented water savings of 26 and 40\% (179 and $268 \mathrm{~m}^{3} \mathrm{ha}^{-1}$ ), in 2014 and 52 and $73 \%$ (249 and $\left.351 \mathrm{~m}^{3} \mathrm{ha}^{-1}\right)$, in 2015 , respectively. The irrigation was carried out taking into consideration the precipitation lost through deep infiltration and runoff. The considered factor was the net storage in the soil. It permitted the planning of the deficit in each treatment with minimal differences in production. The water reserve in the soil coming from rain and irrigation before the rapid fruit growth phase mitigates the effects of reductions of water.

Bud length. The longitudinal growth of the shoots in 2014 and 2015 showed a sigmoid curve, defined by three characteristic phases: The first one with cell division from flowering to 44 and 46 days after flowering (DAF) and rapid growth; the second one 45 and 47 to 92 and 116 DAF with slow cell growth; and the third one with a constant increase from 93 and 117 DAF until after the harvest stage, in which the maximum length was reached, figure 1.

The parameters of the model obtained in 2014 and 2015, with coefficients of determination greater than 0.99 , are shown in table 1 , corresponding to Equation 1.

The bud lengths in T1, T2, and T3 in 2014 were, at the beginning of the restriction (41 DAF) 39.12, 41.45 and $39.53 \mathrm{~cm} ; 70.41$, 72.04 , and $68.43 \mathrm{~cm}$ at the end of the restriction (99 DAF); and $83.17,82.12$, and $77.14 \mathrm{~cm}$ (142 DAF) at harvest, respectively, without any significant differences between treatments. In 2015, the bud lengths were, at the beginning of the restriction (53 DAF) $27.14,30.53$, and $28.02 \mathrm{~cm} ; 45.94,50.58$, and $48.15 \mathrm{~cm}$ at the end of the restriction (114 DAF); and 57.79, 60.20, and $60.16 \mathrm{~cm}(180$ DAF), respectively, without any significant differences between treatments. After 77 DAF (35 days after the restriction, DAR), in 2014 and 101 DAF (48 DAR), in 2015. All this presumably because the stress levels reached were not severe enough, despite significant water savings. With the lowest rainfall, the soil water potential ( $\left.\Psi_{\mathrm{s}}\right)$ and stem potential $(\Psi \mathrm{t})$, as seen in T3, decreased vegetative growth as a result of the effect of water restriction (Vélez Sánchez et al. 2007; Podesta et al. 2010; Hueso et al. 2019).

The maximum bud length in T1, T2, and T3, measured 154 DAF, in 2014 was $85.18,83.53$, and $78.29 \mathrm{~cm}$ and in 2015186 DAF was $58.40,60.60$, and $60.74 \mathrm{~cm}$, respectively, without any significant differences. The shortest shoot length was seen in 2015, because of the lower water regimes applied, as compared to those of 2014. Figure 1, shows that T3 in 2014 during the restriction and most of the crop cycle presented the shortest bud length, fulfilling one of the purposes of (RDI), to reduce the water consumption of the plants through transpiration; in 2015, T1 had the shortest bud length, following the weight of the pruned wood in T2 and T3, which were $15.07 \%$ and $44.23 \%$ lower than the control in 2014 and $6.98 \%$ and $10.47 \%$ lower in 2015 , possibly because of the effect of alternating on deciduous trees (Molina Ochoa et al. 2015a).

The daily growth of the shoot length in 2014 had a difference, between T1 $\left(0.513 \mathrm{~cm} \mathrm{day}^{-1}\right)$ and T3 $\left(0.443 \mathrm{~cm} \mathrm{day}^{-1}\right) 63$ DAF, while in 2015 there was no difference. The daily growth of the deficit treatments at the end of the crop cycle was lower than that of the control in 2014 and higher in 2015, possibly because of the compensatory growth of the fruits once $100 \%$ ETc irrigation was resumed (Figure 1). 

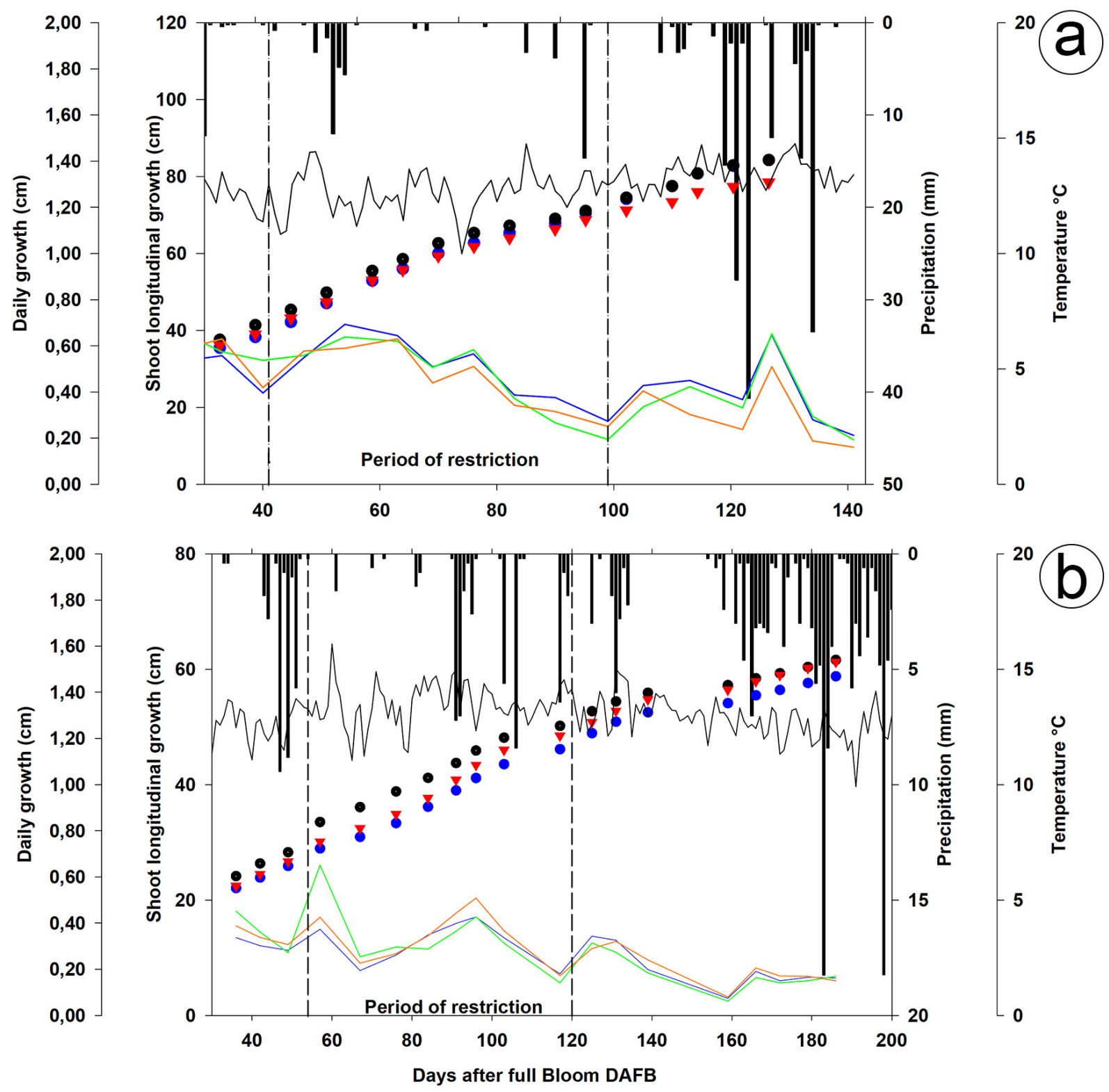

Temperature

T1 Daily growth

T2 Daily growth

T3 Daily growth

Precipitation, $\mathrm{mm}$

- T1 Accumulated growth

T2 Accumulated growth

T3 Accumulated growth

Figure 1. Evolution of length and longitudinal growth of the outbreaks. a. 2014; b. 2015. The values correspond to the average of 96 shoots: 12 per tree, in two trees per repetition, and eight per treatment. Temperature and precipitation (place restriction period).

The absolute rate of growth (AGR) of shoot length. The curve of the (AGR) of the shoot length corresponding to a Gaussian bell that described the daily growth and defined the maximum and the inflection point for T1, T2, and T3 as 0.592 (52 DAF), 0.623 (44 DAF), and $0.607 \mathrm{~cm} \mathrm{day}^{-1}$ (44 DAF), respectively, in 2014 and as 0.302 (70 DAF), 0.375 (60 DAF) and $0.352 \mathrm{~cm} \mathrm{day}^{-1}$ (71 DAF), respectively, in 2015, without significant differences between treatments, which means that, during the two years, T3 accumulated enough dry matter for the fruits to achieve the respective compensatory growth once irrigation was resumed.
The (AGR) of the bud length in 2014 and 2015 corresponded to the growth derivative $(\delta \mathrm{y} / \delta \mathrm{t})$, which resulted in equation 2 , with the parameters of the models obtained from table 1 .

The AGR of the bud length in 2014 for T1, T2, and T3 was, before the restriction (25 DAF), 0.525, 0.578, and $0.567 \mathrm{~cm}^{\text {day }}{ }^{-1} ; 0.580$, 0.622 , and $0.607 \mathrm{~cm} \mathrm{day}^{-1}$ at the beginning of the restriction (41 DAF); $0.417,0.357$ and $0.320 \mathrm{~cm} \mathrm{day}^{-1}$ at the end of the restriction (99 DAF); and $0.146,0.100$ and $0.085 \mathrm{~cm}^{-1}$ day $^{-1}$ at harvest (154 DAF), respectively, without any significant differences. 
Table 1. Parameters of the sigmoid and logistic curve corresponding to the growth length model of the outbreaks and coefficients of determination in 2014 and 2015, respectively.

\begin{tabular}{|c|c|c|c|c|}
\hline Treatment, 2014 & $\mathbf{a}$ & $\mathbf{b}$ & $\mathbf{c}$ & $\mathbf{R}$ \\
\hline T1 & 91.210 & 38.520 & 52.030 & 0.995 \\
\hline T2 & 87.160 & 34.960 & 44.420 & 0.993 \\
\hline T3 & 81.070 & 33.370 & 42.650 & 0.996 \\
\hline Treatment, 2015 & \multicolumn{3}{|c|}{0} \\
\hline T1 & 63.470 & 48.620 & 67.170 & 0.998 \\
\hline T2 & 63.372 & 42.130 & 56.070 & 0.997 \\
\hline
\end{tabular}

In 2015 , it was, before the restriction (25 DAF), $1.282,1.459$ and $1.420 \mathrm{~cm} \mathrm{day}^{-1} ; 1.205,1.239$ and $1.319 \mathrm{~cm} \mathrm{day}^{-1}$ at the beginning of the restriction (53 DAF); $0.481,0.374$ and $0.488 \mathrm{~cm}^{-1}{ }^{-1}$ at the end of the restriction (114 DAF); and after harvest (186 DAF), 0.113, 0.069 and $0.106 \mathrm{~cm} \mathrm{day}^{-1}$, respectively, without any significative differences. Contrary to that seen for the diameter of the fruits; the AGR of the bud length in 2014 in all treatments was on average lower than in 2015.

In the two years at the beginning of the restriction, the AGR in $\mathrm{T} 2$ and $\mathrm{T} 3$ was higher than in $\mathrm{T} 1$, because of the water reserve in the soil coming from the rain and the irrigation before the rapid fruit growth phase. In 2014 at the end of the restriction before the harvest was lower, while in 2015, T2 was lower than T1 and T3 (Figure 2).

Relative growth rate (RGR) of shoot length. The relative growth rate (RGR) of the shoot length during the two years showed a decreasing trend in all treatments, with a rapid decrease at the beginning. The RGR of the bud length in 2014, in T1, T2 and T3 was, before the restriction (25 DAF) $0.0174,0.0182$ and $0.0189 \mathrm{~cm}$ day $^{-1}$; at the beginning of the restriction (41 DAF), 0.0148, 0.0150 and $0.0154 \mathrm{~cm} \mathrm{day}^{-1}$; at the end of the restriction (99 DAF), 0.0059, 0.0050 and $0.0047 \mathrm{~cm} \mathrm{day}^{-1}$ and, before harvest (154 DAF), 0.0017, 0.0012 and $0.0010 \mathrm{~cm} \mathrm{day}^{-1}$, respectively, without any significant differences. In 2015, before the restriction (25 DAF), it was $0.0683,0.0711$ and $0.0747 \mathrm{~cm} \mathrm{day}^{-1}$; at the beginning of restriction (53 DAF), 0.0444, 0.0406 and $0.0471 \mathrm{~cm} \mathrm{day}^{-1}$; at the end of the restriction (114 DAF), $0.0105,0.0074$ and $0.0101 \mathrm{~cm} \mathrm{day}^{-1}$ and, after harvest (186 DAF), 0.0019, 0.0011 and $0.0017 \mathrm{~cm} \mathrm{day}^{-1}$, respectively, without any significant differences.

In the two years before the start of the restriction, the RGR in T2 and T3 was higher than in T1, and, at the end of the restriction and before the harvest, they were smaller, coinciding with the conditions of the treatments. The RGR in T1, T2, and T3 reached its maximum at the beginning of growth: 0.0174, 0.0182, and $0.0189 \mathrm{~cm} \mathrm{day}^{-1}$, respectively, in 2014. In 2015, the RGR was 0.0683 , 0.0711 and $0.0747 \mathrm{~cm} \mathrm{day}^{-1}$, without significant difference between treatments, similar to the results reported by Molina Ochoa et al. (2015b), Díaz Abril et al. (2016) and Vélez Sánchez et al. (2007) (Figure 3). The (RGR) of the bud length in 2014 and 2015 was determined with the models of the absolute growth rate calculated with Equation 3, and the resulting parameters of table 1.

Comparison between the growth of the fruits and the buds. In 2014 for all treatments, the percentage of fruit growth was greater than the one for the buds in the initial stage. In 2015 the opposite occurred, possibly because of rainfall occurring between 40 and 55 DAF.

The percentage growth of the buds was greater than the fruits for all the treatments as a result of the water restrictions for two years. It coincided with the period of the slow growth of the fruits, and the rapid growth of the buds, resulting from the competition between them (Yang et al. 2016).

$\mathrm{T} 2$ and T3 presented the highest percentage of shoot growth and the lowest percentage of fruit growth. The greatest differences in percentages of growth between the shoots and fruits were seen in T2 $(17.29 \%)$, higher than T3 $(14.90 \%)$ and T1 $(8.47 \%)$ at 76,69 , and 90 DAF in 2014, respectively. In 2015, T2 (15.81\%) was higher than T3 (13.93\%) and T1 (11.06\%) up to 103 DAF (Figure 4).

This behavior occurs when plants have decreased water supply and accumulate carbohydrates in the cellular structures that maintain it until transferred to the fruits or stored after harvest for use in the following season. This could be verified with the lower pruned wood weights in the deficit treatments, along with the volumetric humidities $(\Theta \mathrm{v})$, soil water potentials $(\Psi \mathrm{s})$, stem potentials $(\Psi \mathrm{t})$ and rainfall, but with the same number and average weight of the fruits, which presented no differences in 2014 and 2015.

The lower percentage of fruit growth in 2014 and 2015 in the deficit treatments was also due to other factors, such as pruning and the level of stress to which the plant was subjected. This allowed for the separation of the vegetative and fruit growth, which occurs after the end of shoot growth, similar to that found by Marsal et al. (2002), in the pear. 

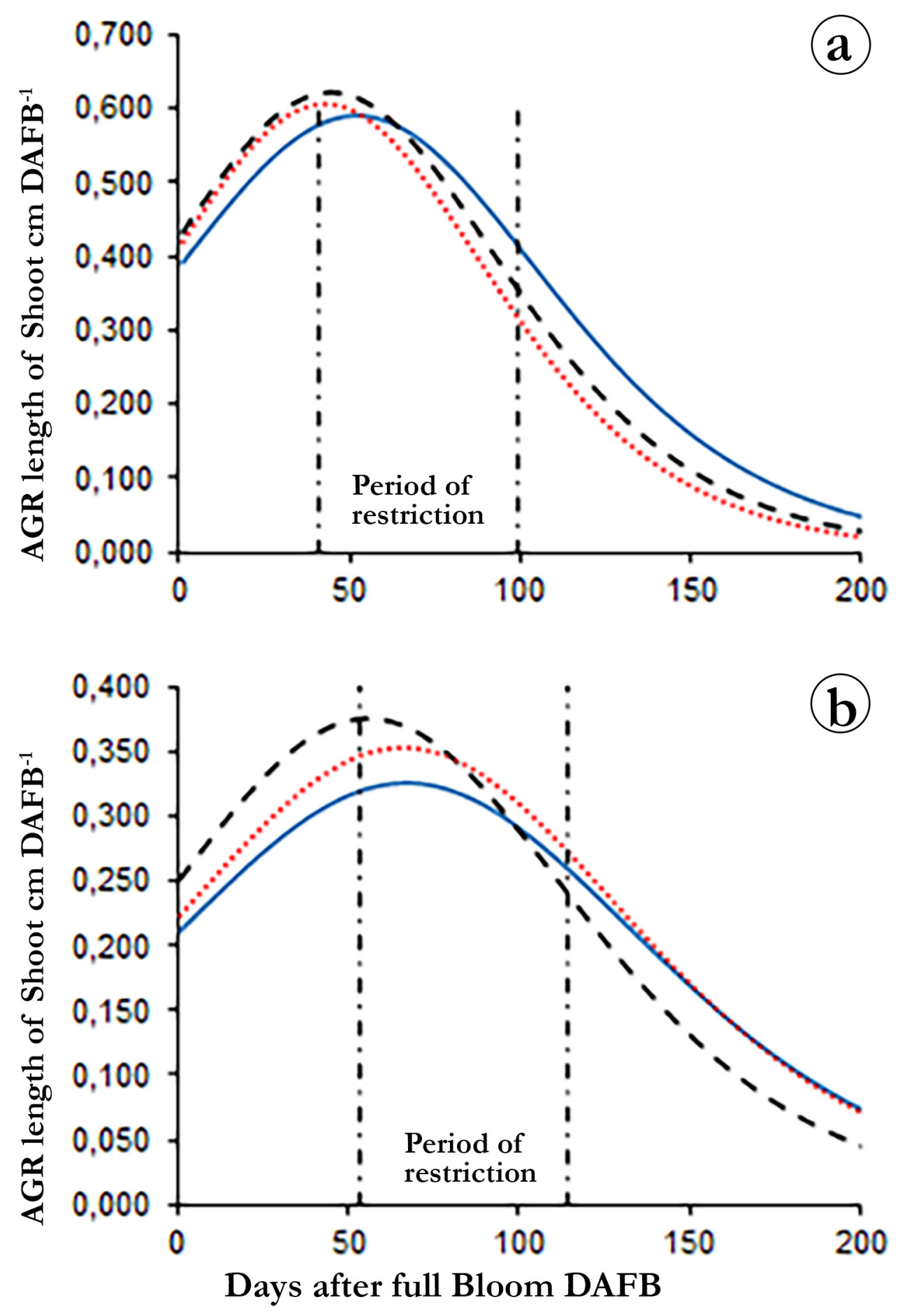

- Control T1 _ - - T2

Figure 2. Longitudinal absolute growth rate (AGR) of the outbreaks. a. 2014; b. 2015. The values correspond to the average of 96 shoots: 12 per tree, in two trees per repetition and eight per treatment.

Figure 5 summarizes the evolution of the different water status indicators of soil and plants during the trial and show that, as the $\Psi$ s decreased, the leaf water potentials at dawn $(\Psi \mathrm{a})$ decreased as did the stem potential $(\Psi \mathrm{t})$, suggesting a relationship between these variables with the use of the water reserves of the plants. The influence of precipitation on each one was also observed: when it rained or the potentials were irrigated, they were equal and decreased, and even became smaller in the deficit treatments with respect to the control. This potential was a good indicator of state hydric of plant. 

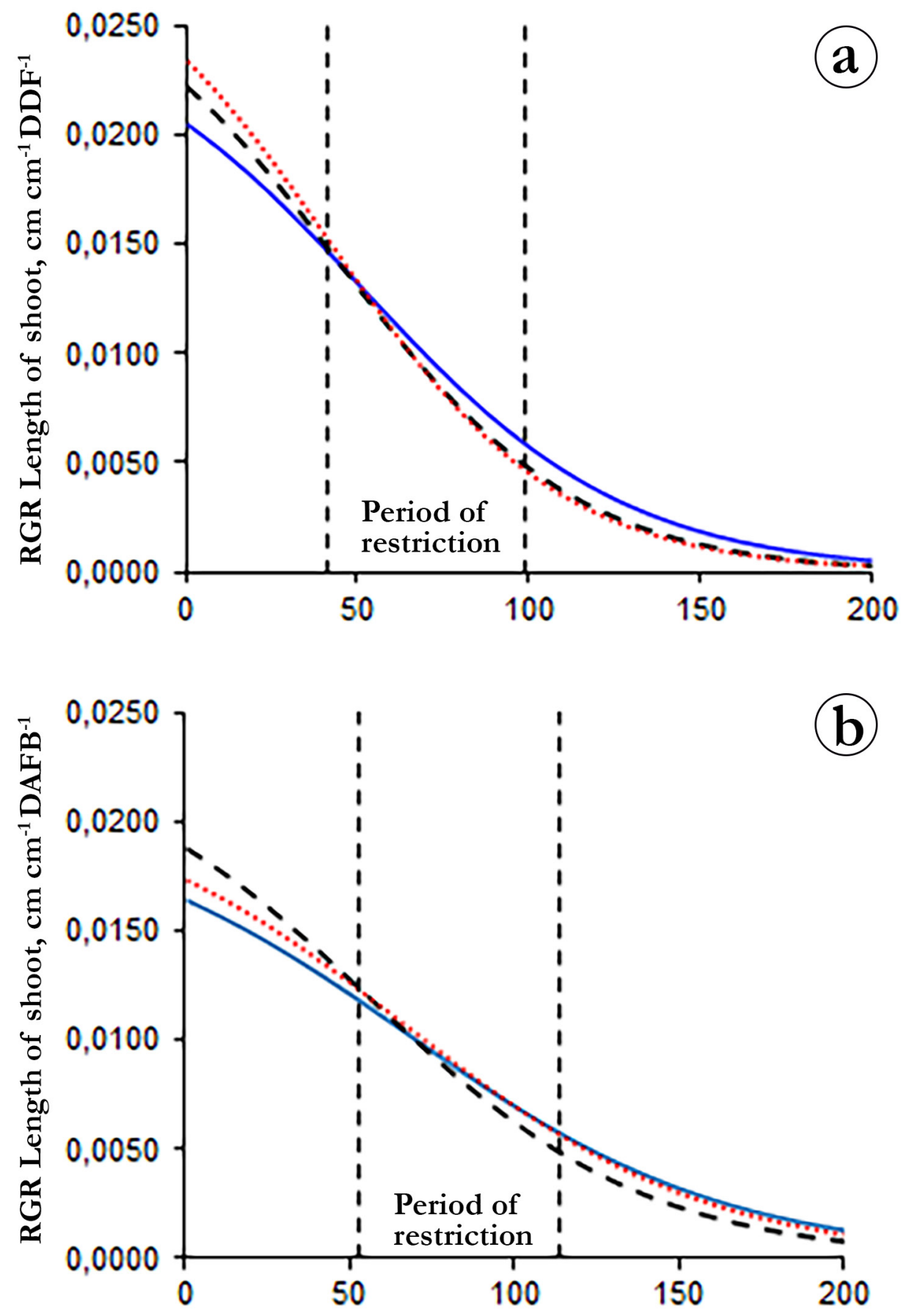

Days after full Bloom DAFB

Control T1 - - T2 T3

Figure 3. Relative growth rate (RGR) of shoot length. a. 2014; b. 2015. The values correspond to the average of 96 shoots: 12 per tree, in two trees per repetition and eight per treatment.

With the imposition of the deficit, the $\Psi \mathrm{a}$ and $\Psi \mathrm{t}$, as expected, tended to decrease: the smallest regime (T3) had $\Psi$ a values of $-0.29 \mathrm{MPa}$ and $\Psi \mathrm{t}$ values of -0.80 and $0.99 \mathrm{MPa}$ in 2014 and 2015, respectively. T2 had similar values of $\Psi \mathrm{a}(-0.26 \mathrm{MPa})$ and $\Psi \mathrm{t}(-0.78$ $\mathrm{MPa}$ and $0.96 \mathrm{MPa}$ ), in 2014 and 2015, respectively, while, in the control, the $\Psi$ a was $-0.30 \mathrm{MPa}$ and the $\Psi$ t was -0.70 and $1.03 \mathrm{MPa}$ in 2014 and 2015, respectively.

Pruned wood weight. One of the objectives of the RDI was to avoid excess plant vigor so as not to have negative effects on the production, which was achieved because of the clear separation that was found in this variety between the vegetative growth of the 


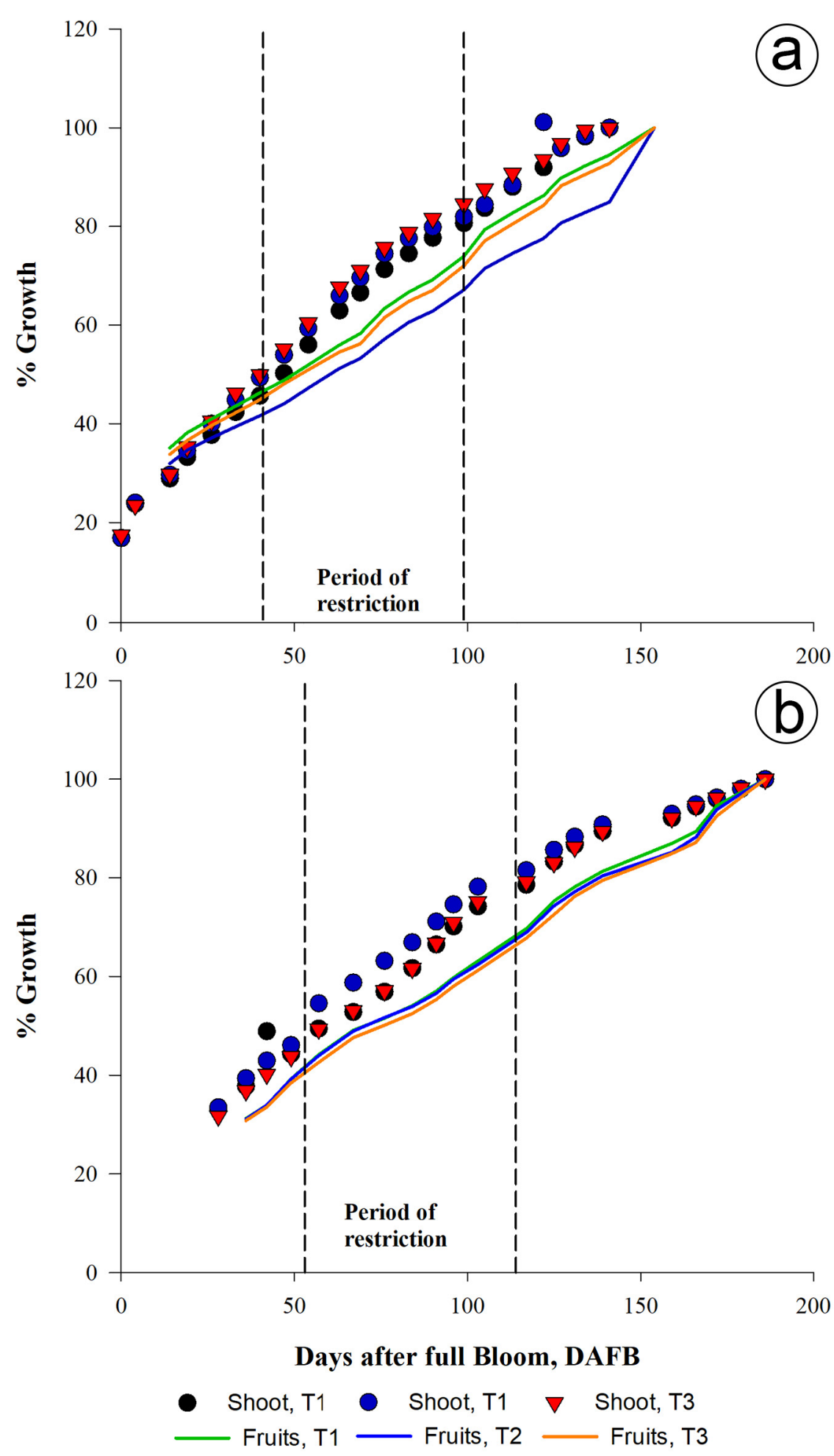

Figure 4. Comparison of the percentage of longitudinal growth of shoots and diameter of fruits. a. 2014; b. 2015. The values correspond to the average of 96 shoots and fruits, respectively: 12 per tree, in two trees per repetition and eight per treatment.

shoots and the growth of the fruits, where part of the growth of the fruit occurred after the end of the vegetative growth (Figure 4).

The results in 2014 showed an increase in the weight of the pruned wood in T1, which had the greatest volume of water applied, as compared to T2 and T3, $17.75 \%$ and $79.31 \%$, respectively, with a difference, from that of T3. In 2015, there was no difference, between the treatments although the wood weight was lower in T3 and T2, 9.35\% and 5.25\%, than in T1. This indicates that the decrease in the vigor of the trees was achieved through the RDI. 

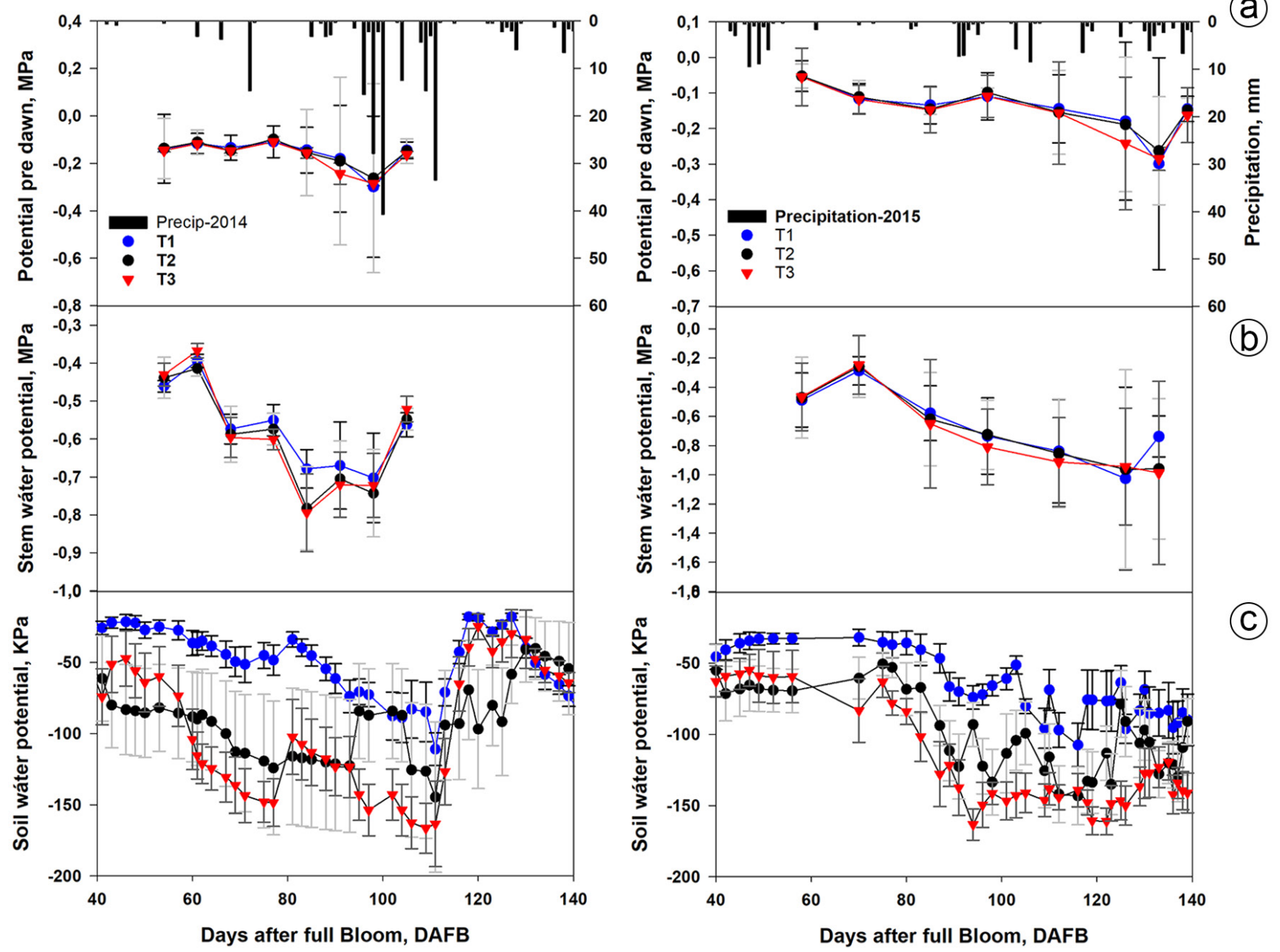

Figure 5. Evolution of the indicators of soil and plant water status in irrigation treatments in 2014 and 2015. a. water potential of the leaf at dawn ( $\Psi \mathrm{a})$ and precipitation; b. water potential of the leaf to the stem $(\Psi \mathrm{t})$, c. soil water potential $(\Psi \mathrm{s})$, The values correspond to the means of two leaves per tree in each repetition, in eight trees per treatment. The bars correspond to the standard error.

However, in the control T1 treatment, there was no difference between the two years, while in T2 and T3 there was. The vigor increased, which could be verified in the same plot in 2013 through the effect of the deficit treatments carried out in 2012 (Molina Ochoa et al. 2015b). This variation was very marked in the pome fruit trees because the floral buds can also develop leaves and short branches, which does not happen in drupe fruit trees, where the formation of fruits and flowers has a greater separation (Fischer, 2012). The lower volumes of wood also mean important savings because of the high labor costs for pruning (Martínez et al. 2019).

When there is a decrease in the slope of the daily growth curve of the outbreaks longitudinal, the plant begins to experience slight water stress that signals the start of irrigation, which is why it is used as a highly sensitive indicator of stress.

The bud growth curve was fit to a sigmoid logistic type with three parameters, with which the AGR and RGR were determined, which allows for coordination of the irrigation in such a way that the vegetative growth is controlled to reduce water consumption through transpiration (Panigrahi \& Srivastava, 2016).
These results indicate the possibility of programming the automating irrigation when there is no previously established reference equation, and well-watered trees are available in the same plot. It is needed to monitor the water status of the plants continuously, so the imposed deficit does not reach too severe stress situations that could compromise productivity (Vélez Sánchez et al. 2012).

Acknowledgments: We are grateful to the Universidad Nacional de Colombia and Acqua Irrigacion Ltda, for funding this research through the deficit irrigation project. Conflicts of interest: The manuscript was prepared and revised by all authors, who declare the absence of any conflict which can put the validity of the presented results at risk.

\section{REFERENCES}

1. ALLEN, R.G.; PEREIRA, L.S.; RAES, D.; SMITH, M. 1998. Crop evapotranspiration, guidelines for computing crop water requirements. Irrigation and Drainage Paper 56. FAO. Roma. 
2. ÁLVAREZ, J.; FISCHER, G.; VÉLEZ, J. 2021. Análisis de la producción de uchuva (Physalis perwiviana L.) durante el ciclo de cosechas en invernadero con diferentes láminas de riego. Rev. Acad. Colomb. Cienc. Ex. Fis. Nat. 45(174):109-121. https://doi.org/10.18257/raccefyn.1239

3. ARDILA, G.; FISCHER, G.; BALAGUERA-LÓPEZ, H. 2011. Caracterización del crecimiento del fruto y producción de tres híbridos de tomate (Solanum lycopersicum L.) en tiempo fisiológico bajo invernadero. Rev. Col. Ciencias Hortícolas. 5(1):44-56.

https://doi.org/10.17584/rcch.2011v5i1.1252

4. BOLAT, I.; DIKILITAS, M.; ERCISLI, S.; IKINCI, A.; TONKAZ, T. 2014. The effect of water stress on some morphological, physiological, and biochemical characteristics and bud success on apple and quince rootstocks. The Scientific World J. 8:769732.

https://doi.org/10.1155/2014/769732

5. ClEVES-LEgUiZAMO, J.A.; TORO-CALDERÓN, J.; MARTÍNEZ-BERNAL, L. 2016. Los balances hídricos agrícolas en modelos de simulación agroclimáticos. Una revisión analítica. Rev. Colomb. Cienc. Hortic. 10(1):149-163. https.//doi.org/10.17584/rcch.2016v10i1.4460

6. DÍAZ ABRIL, D.M.; VÉLEZ SÁNCHEZ, J.E.; RODRÍGUEZ HERNÁNDEZ, P. 2016. Efecto de la aplicación de riego controlado en la producción y calidad del fruto de Pyrus communis L. cv. Triunfo de Viena. Acta Agronómica. 65(2):156-163.

http://dx.doi.org/10.15446/acag.v65n2.49650

7. FISCHER, G. 2012. Comportamiento de los frutales caducifolios en el trópico. En: Miranda, D.; Fischer G.; Carranza, C. (eds.). Los frutales caducifolios en Colombia: Situación actual, sistemas de cultivo y plan de desarrollo. Sociedad Colombiana de Ciencias Hortícolas. Bogotá. p.25-40.

8. HUESO, A.; TRENTACOSTE, P.R.; JUNGUERA, P.; GÓMEZ-MIGUEL, V.; GÓMEZ DEL CAMPO, M. 2019. Differences in stem water potential during oil synthesis determine fruit characteristics and production but not vegetative growth or return bloom in an olive hedgerow orchard (cv. Arbequina). Agricultural Water Management. 223:105589.

https://doi.org/10.1016/j.agwat.2019.04.006

9. INSTITUTO GEOGRÁFICO AGUSTÍN CODAZZI, IGAC. 2010. Clasificación de suelos en el departamento de Cundinamarca. En asociación con la Universidad Tecnológico y Pedagógica de Colombia. Departamento Nacional de Estadística, subdirección de Agrología. 169:325-327.
10. MARSAL, J:; MATA, M.; ARBONÉS, A.; RUFAT, J.; GIRONA, J. 2002. Regulated deficit irrigation and rectification of irrigation scheduling in young pear trees; an evaluation based on vegetative and productive response. European J. Agronomy. 17:111-122. https://doi.org/10.1016/S1161-0301(02)00002-3

11. MARTÍNEZ, J.; GALINDO, A.; GRIÑÁN, I.; RODRÍGUEZ, P.; CRUZ, Z.N.; MARTÍNEZ-FONT, R.; CARBONEL BARRACHINA, A.; NOURI, H.; MELGAREJO, P. 2019. Irrigation wáter saving during pomegranate flowering and fruit set period do not affect Wonderful and Mollar de Elche cultivars yield and fruit composition. Agricultural Water Management. 226:1-7.

https://doi.org/10.1016/j.agwat.2019.105781

12. MOLINA OCHOA, M.J.; VÉLEZ SANCHEZ, J.E.; GALINDO-EGEA, A. 2015a. Resultados preliminares del efecto del riego deficitario durante el periodo de crecimiento rápido del fruto de pera (var. Triunfo de Viena) en la producción y calidad del fruto. Agr. Col. 9(1):38-45. http://dx.doi.org/10.17584/rcch.2015v9i1.3744

13. MOLINA OCHOA, M.J.; VÉLEZ SANCHEZ, J.E.; RODRIGUEZ HERNÁNDEZ, P. 2015b. Effect of regulated deficit irrigation on tree growth of pear cv. Triunfo de Viena. Agr. Col. 33(3):330-338.

https://doi.org/10.15446/agron.colomb.v33n3.50756

14. MORENO HERNANDEZ, A.; VÉLEZ SANCHEZ, J.E.; INTRIGLIOLO, D. 2017. Effect of deficit irrigation on yield and quality of pear (Pyrus communis cv. Triumph of Vienna). Agr. Col. 35(3):350-356.

https://doi.org/10.15446/agron.colomb.v35n3.64313

15. PANIGRAHI, P.; SRIVASTAVA, A.K. 2016. Effective ma nagement of irrigation water in citrus orchards under a water-scarse hot sub-humid región. Scientia Horticulturae. 210:6-13.

https://doi.org/10.1016/j.scienta.2016.07.008

16. PODESTA, L.; SÁNCHEZ, E.; VALLONE, R.; MORABITO, J.A. 2010. Efecto del riego deficitario controlado sobre el crecimiento vegetativo en plantaciones jóvenes de cerezo (Prunus avium L.). Rev. FCA UN Cuyo. 42(1):73-91.

17. SAS INSTITUTE INC. 2010. Statistical Analysis System Version 8 for Windows Inc. Cary, NC. USA.

18. SILVEIRA, L.K.; PAVAO, G.C.; SANTOS DIAS, C.T.; QUAGGIO, J.A.; MATOS PIRES, R.C. 2020. Deficit irrigation effect on fruit yield, quality and water use efficiency: A long-term study on Pêra-IAC sweet Orange. Agricultural Water Management. 231:106019. https://doi.org/10.1016/j.agwat.2020.106019 
19. VÉLEZ SÁNCHEZ J.E; INTRIGLIOLO, D.S.; CASTEL SÁNCHEZ, J.R. 2007. Scheduling deficit irrigation of citrus trees with maximum daily trunk shrinkage. Agricultural Water Management. 90(3):197-204.

https://doi.org/10.1016/j.agwat.2007.03.007

20. VÉLEZ SÁNCHEZ, J.E; INTRIGLIOLO, D.S.; CASTEL SÁNCHEZ, J.R. 2012. Programación de riego en cítricos en base a sensores de medida del estado hídrico del suelo y de la planta. Rev. U.D.C.A. Act. \& Div. Cient. 14(2):65-73.

https://doi.org/10.31910/rudca.v14.n2.2011.776

21. WU, Y.; ZHAO, Z.; WANG, W.; MA, Y.; HUANG, X. 2013. Yield and growth of mature pear trees under water deficit during slow fruit growth stages in sparse planting orchards. Scientia Horticulturae. 164:189-195.

https://doi.org/10.1016/j.scienta.2013.09.025
22. YANG, W.; PALLAS, B.; DURAND, J.; MARTINEZ, S.; HAN, M.; COSTES, E. 2016. The impact of long-term water stress on tree architecture and production is related to changes in transitions between vegetative and reproductive growth in the 'Granny Smith' apple cultivar. Tree Physiology. 36(11):1369-1381.

https://doi.org/10.1093/treephys/tpw068 